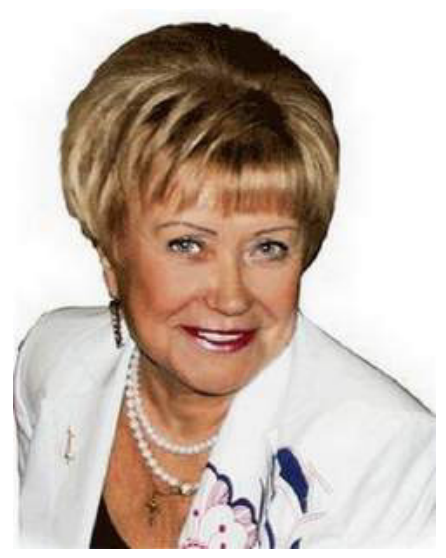

Алла Богуш,

доктор педагогічних наук, професор,

Державний заклад «Південноукраїнський національний педагогічний університет імені К.Д.Ушинського»

(м. Одеса)

\author{
Alla Bohush, \\ Doctor of Pedagogical Sciences, Professor, \\ National Pedagogical University \\ named after K. D. Ushynskyj \\ (Odesa)
}

\title{
ВПЛИВ ПОЛІКУЛЬТУРНОГО МОВЛЕННЄВОГО СЕРЕДОВИЩА НА ФОРМУВАННЯ МОВНОЇ ОСОБИСТОСТІ
}

\section{INFLUENCE OF POLICULTURAL LINGUISTIC ENVIRONMENT ON FORMATION OF LINGUISTIC PERSONALITY}

\footnotetext{
У статті подано аналіз феномена «мовна особистість», його змістового визначення різними вченими; розкрито авторське розуміння дефініцій «мовна особистість», «полікультурне мовленнєве середовище» та визначено чинники впливу на формування мовної особистості.

Ключові слова: мовна особистість, мовленнєва особистість, полікультурне мовленнєве середовище, розвивальне мовленнєве середовище, чинники.

The article deals with analysis of the phenomenon "speech personality» and the definition of this notion by different authors; the author's interpretation of definitions "speech personality» and "polycultural speech environment» has been revealed in it; the factors which influence the formation of the language personality have been defined.

Key words: language personality, speech personality, polycultural speech environment, speech environment, factors.

В статье представлен анализ феномена «языковая личность», его содержательного определения различными учеными; раскрыто авторское понимание дефиниций «языковая личность», «поликультурная речевая среда» и определены факторы влияния на формирование языковой личности.

Ключевые слова: языковая личность, речевая личность, поликультурная речевая среда, развивающая речевая среда, факторы.
}

Однією з провідних психічних функцій людини є мовлення, яке дозволяє їй задовольнити найважливішу специфічно людську потребу - потребу у спілкуванні, цю єдину, справжню розкіш, розкіш людського спілкування. Загальновідомо, що спілкування людей завжди відбувається в межах певної культури із використанням конкретної етнічної мови, законів і правил спілкування, що склалися в межах конкретної мови і культури.

Зауважимо, що сьогоденній мовленнєво-культурній картині України притаманна полікультурність. Загальна глобалізація світу, що спостерігається сьогодні, породила одну із головних суперечностей сьогодення, а саме: між прагненням до все більшого зближення між народами та їхнім бажанням зберегти свою етнокультурну самобутність . Потрапляючи в інше культурно-мовленнєве середовище, мовець фактично потрапляє в інший світ соціокультурних цінностей і мовно-мовленнєвих законів спілкування, що породжує нову суперечність: між прагненням мовця оволодіти декількома мовами задля міжкультурного спілкування і необхідністю досконалого володіння своєю рідною та державною мовами в багатонаціональній державі. Відтак, виникає низка мовленнєво-культурних проблем, які вимагають серйозних досліджень і їх розв'язання, як-от: багатомовність, полілінгвістична освіта в полікультурному мовленнєвому середовищі, виховання полімовної особистості в полікультурному освітньому середовищі.

Виховання і навчання особистості в полікультурному просторі стали предметом дослідження багатьох учених (Р. Агадуллін, Л.У. Алімова, Ф.Е. Бацевич, Н.В. Бондаренко, О.В. Гукаленко, І.П. Гудзик, Г. Дмитрієв, Н.Е. Миропольська, А.К. Солодка та ін. ).

В Україні розроблено концепцію шкільної мовної освіти національних спільнот. Необхідність такої концепції зумовлена необхідністю гармонізувати взаємодію етносів полієтнічної держави у процесах українотворення, зрослим попитом суспільства на мислячу, діяльну, творчу, національно-свідому особистість, визначальною роллю мови у її формуванні та невідповідністю традиційної системи навчання мов проблемам сьогодення [5:12]. Одним із провідних принципів навчання мов в Україні виступає полікультурний підхід.

Полікультурний підхід щодо формування змісту мовної освіти передбачає вивчення мови не ізольовано, а в контексті представленої нею духовності й культури, взаємозв'язків з духовними надбаннями народів, які 
живуть поруч, створення передумов для паритетного діа- та полілогу культур, їх взаємозбагачення, інтеграції в національно-українську культуру і разом з нею - у світову [5:13].

3-поміж завдань формування мовної освіти можна виокремити такі: навчити мовців міжкультурного спілкування, міжкультурного взаєморозуміння, виховати відповідну мовленнєву поведінку в полікультурному мовленнєвому середовищі.

Зауважимо, що ЮНЕСКО оголосив XXI століття «століттям поліглотів», оскільки саме багатомовність забезпечить особистості варіативність «духовного життя і плюралізм культур». Мова як знаряддя духовної творчості забезпечує, за словами Н.Е. Миропольської, з одного боку, індивідуальну самобутність, неповторність духовного розвитку, а з іншого - можливість інтеграції індивідуального й національного в загальнолюдське [14:115].

Оволодіння людиною кількома мовами, своєрідність кожної з них Г. Гачев називає «закоханою несхожістю народів, яка тільки і складає багатокольорову мозаїку духовного життя людства» [6:19].

Відомий дослідник історії слова М. Бахтін зазначав, що мова розквітає тільки за умов багатомовності [2]. Через різноманітність мов для нас відкривається багатство світу і різноманітність того, що ми пізнаємо в ньому; і людське буття стає для нас ширшим, оскільки мови в чітких і дієвих рисах дають нам різні способи мислення і сприймання. Мова завжди втілює в собі своєрідність цілого народу [8:349]. Фердінанд де Соссюр відкрив у людській мові два фактори, що ніколи не перестають діяти: локальне, відокремлене спрямування або, за його словами, «дух рідної дзвіниці», з одного боку, і об'єднуючу силу мовленнєвої взаємодії, з другого [15].

Метою мовної освіти у багатомовному регіоні повинно стати формування всебічно-розвиненої, компетентної, творчої особистості громадянина України - носія етнічних, національних і загальнолюдських цінностей, що живе в гармонії з довкіллям і самим собою; навчити розуміти нову культуру (міжкультурне взаєморозуміння); оволодіти міжкультурною комунікацією, тобто вмінням спілкуватися з носіями іншої культури. Предметом навчання у школах етноспільнот повинна бути не стільки мова, виключена з системи практичних дій, скільки представлена нею думка, духовність, мовленнєва і загальна культура, особливості світосприймання, світовідчуття і творчості народу - її носія. Мова може і повинна стати культурознавчою дисципліною $[5: 16,17]$.

Така стратегія побудови мовної освіти в полікультурному просторі спричинює нас визначити ключові поняття, які підлягатимуть надалі експериментальному дослідженню, а саме: мовна і мовленнєва особистість, полікультурне мовленнєве середовище, його специфіка і види та вплив мовленнєвого середовища на формування мовної особистості.

Незаперечною є теза: «з слова починається людина». Відтак, можна впевнено сказати, що історія людства здійснюється у спілкуванні, засобами мови, а однією з провідних умов соціального прогресу суспільства виступає мовленнєва діяльність. Успіх мовленнєвої діяльності, її результативність, у свою чергу, залежить від особистості, від рівня розвитку її мовлення, від культури мови і мовлення особистостей - мовців, які беруть участь у мовленнєвій діяльності. Саме тому науковці останнім часом звернулися до дослідження такого наукового феномена, як «мовна особистість» (Г.І. Богін, Й. Вейсгербер, Т.М. Дрідзе, Ю.М. Караулов. О.О. Леонтьєв, В.А. Маслова, Л.І. Мацько, І.П. Суслов, С.О. Сухих, В.В. Тарасун та ін.).

Ю.М. Караулов розробив рівневу модель мовної особистості, яка, на його думку, має три структурних рівня: вербально-семантичний, когнітивний і найвищий - прагматичний. Означені три рівні мовної особистості, за словами автора, співвідносяться з трьома аспектами процесу спілкування: комунікативним, інтерактивним і перцептивним [10:99]. Зауважимо, що Ю.М. Караулов схарактеризував узагальнений тип мовної особистості.

В.А. Маслова описує такі структурні компоненти мовної особистості, як от:

- ціннісний, світоглядний, компонент змісту виховання, що є основою формування національного характеру і реалізується у процесі мовного діалогового спілкування;

- культурологічний компонент, пов'язаний із засвоєнням культури як загальнолюдської, так і національної, це правила мовленнєвої і немовленнєвої поведінки;

- особистісний компонент, це те індивідуальне і глибинне, що притаманне кожній людині [12: 119].

В.В. Красних подає своє бачення структурних компонентів мовної особистості, а саме:

- людина - мовець, тобто особистість, одним із видів діяльності якої є мовленнєва діяльність;

- власне мовна особистість - це особистість, яка виявляє себе в мовленнєвій діяльності, при цьому володіє сукупністю знань і уявлень;

- мовленнєва особистість, яка реалізує себе в комунікації, обирає і здійснює певну стратегію і тактику спілкування, репертуар засобів;

- комунікативна особистість - конкретний учасник конкретного комунікативного акту, яка реально діє в реальній комунікації [10].

У роботах учених (Ю.М. Караулов, В.В. Красних, В.А. Маслова та ін.), як бачимо, особистість розмежовується на два види: мовну і мовленнєву. На думку Ю.М. Караулова, узагальнений тип мовної особистості передбачає розмаїття варіантів мовленнєвих особистостей. Мовленнєва особистість, за його словами, це мовна особистість у парадигмі реального спілкування, в діяльності; у свою чергу, мовна особистість - це багатошарова і полікомпонентна парадигма мовленнєвих особистостей [10:119].

Основним засобом перетворення індивіда в мовну особистість В.А. Маслова називає соціалізацію у їі трьох аспектах: а) процес включення людини в певні соціальні відносини; б) мовленнєво-мисленнєва діяльність за нормами і законами певної етномовної культури; в) процес засвоєння законів соціальної психології народу [12:121]. 
Не можна не погодитись, що мовна особистість це насамперед соціальне явище, вона пов'язана із соціально - культурно-етнічною сферою суспільства. Відтак, процес соціалізації особистості буде відбуватися по-різному в залежності від характеру соціального середовища і зокрема, мовленнєвого середовища. Водночас не можна ігнорувати, як на мою думку, в мовній особистості й індивідуально-психологічний аспект, тобто не можна розмежовувати мову і мовлення в мовній особистості, вони зумовлюють одне одного і взаємопов'язані.

Відтак, під мовною особистістю ми розуміємо високорозвинену особистість, носія як національно-мовленнєвої так і загальнолюдської культури, який володіє соціокультурним і мовним запасом, вільно спілкується рідною, державною та іншими мовами в полікультурному просторі, адекватно застосовує набуті полікультурні знання, мовленнєві вміння і навички у процесі міжкультурного спілкування з різними категоріями населення.

Мовна особистість не є вродженою, вона формується і розвивається у процесі навчання, виховання, спілкування, тобто в різних видах діяльності. Започатковується формування мовної особистості вже в ранньому віці, з моменту оволодіння дитиною активним мовленням. Що ж виступає провідним фактором формування мовної особистості в ранньому, дошкільному та й шкільному віці? На мою думку, - це мовленнєве середовище, в якому дитина виховується, навчається, розвивається, відбувається її соціалізація.

Вплив середовища на людину не однобічний: людина послідовно діє у системах «середовище-людина», «людина - середовище». Означена взаємодія зумовлює і розвиток усіх психічних процесів і функцій людини, які пов'язані з середовищем. Водночас високий рівень розвитку психічних процесів дозволяє людині цілеспрямовано впливати на середовище і змінювати його.

Відтак, виховання мовленнєвої культури, культури спілкування, формування мовної особистості і мовленнєвої поведінки багато в чому залежить від специфіки мовленнєвого середовища. Насамперед визначимо і схарактеризуємо поняття «мовленнєве середовище».

Під мовленнєвим середовищем ми розуміємо сукупність сімейних, побутових, соціально-педагогічних неорганізованих і цілеспрямованих умов спілкування мовців у системах «дорослий (батьки, родичі, вихователь, учитель) - дитина», «дитина-дорослий», «дитина-дитина», «дорослий-дорослий».

Мовленнєве середовище може бути: одномовним, в якому спілкування відбувається рідною мовою; одномовно-діалектним; двомовним (близькоспоріднені мови); двомовним, в якому функціонує мовлення різних неспоріднених мов (молдавська - українська, українська - угорська) та багатомовним, яке прийнято йменувати полікультурним середовищем або «полікультурним освітнім простором», за термінологією О.В. Гукаленко [7].

Вочевидь, виникає необхідність визначити феномен «полікультурне мовленнєве середовище», оскільки Україна $€$ багатонаціональною державою, у якій різні полінаціональні спільноти проживають на єдиному територіальному просторі з різними мовами спілкування (Прикарпаття, Південь, Крим і т. ін.)

Полікультурне мовленнєве середовище ми розуміємо як обмежений, соціокультурний, комунікативнобагатомовний простір, на території якого спільно проживають і співпрацюють мовці різних національностей, які володіють своєю рідною мовою, і водночас об'єднані однією (чи декількома) державною мовою, які підпорядковуються основним комунікативним законам і правилам міжкультурного і міжнаціонального спілкування.

Мовленнєве середовище, що оточує мовця, за своїм впливом на розвиток мовлення може бути стихійнонестимульованим, стимульованим і актуальним. Стихійно-стимульованому мовленнєвому середовищу властива пасивна мовленнєва взаємодія. Мовець сприймає мовлення дорослих і всіх мовців цього середовища таким, яким вона його чує, мовлення, що притаманне саме цій мовленнєвій спільноті. Дитина-мовець відчуває його вплив опосередковано у процесі щоденного спілкування у сім'ї, в соціумі (у дворі, з друзями, у дошкільному закладі, у школі і т. ін.). Стихійно-нестимульоване багатомовне мовленнєве середовище породжує явища інтерференції, спричиняє неусвідомлені дитиною мовленнєві помилки на основі проникнення елементів однієї мови в мовлення іншими мовами.

Стимульоване багатомовне мовленнєве середовище - це організований процес навчання декількох мов і розвитку мовлення на різних вікових етапах у навчальних закладах різного типу, що супроводжується педагогічно стимульованою мовленнєвою взаємодією педагога і учнів. Стимульоване полікультурне середовище запобігає інтерферуючих впливів, сприяє усвідомленому засвоєнню мовцем з раннього віку двох і більше мов під керівництвом педагога - носія декількох мов, тобто біглота чи поліглота.

Актуальне полікультурне мовленнєве середовище - це максимально активна ініціативна взаємодія мовця з іншими учасниками спілкування, - багатомовними мовцями; це занурення мовця в активну багатомовленнєву діяльність в обмеженому міжкультурному просторі (музичні ранки, міжнаціональні свята, залучення до виконання різнонаціональних обрядів, звичаїв, традицій; знайомство з національним одягом, посудом, їжею, етикетом і т. ін.).

Ефективний вплив полікультурного мовленнєвого середовища на мовців та їхнє мовлення буде тільки за наявності розвивальної функції цього середовища. Що ми розуміємо під розвивальним полікультурним мовленнєвим середовищем?

Розвивальне полікультурне мовленнєве середовище - це потенційні можливості позитивного впливу різноманітних факторів у їх взаємодії на мовленнєвий розвиток мовця і формування багатомовної особистості (біглота, поліглота), вільне володіння як різною мовою етнічної спільноти, так і державною та іноземною.

Зазначимо, що розвивальний потенціал може мати як стихійне, так і організоване мовленнєве середовище. Це залежить насамперед від якості мовлення, культури мовлення та мовної особистості мовців, з якими вона постійно спілкується, та інших стимульованих факторів.

Одним із провідних стимульованих чинників впливу на мовленнєвий розвиток дитини-мовця в полікультурному середовищі є без сумніву мовлення дорослих, слово педагога, вихователя, який бездоганно володіє двома (чи 
декількома) мовами. І в цьому відношенні не можна не погодитись із педагогічним кредом В.О. Сухомлинського: «Слово в певному розумінні є єдиним засобом виховання і розвитку особистості» [16].

Серед стимульованих чинників мовленнєвого розвитку дитини в полікультурному середовищі можна назвати й такі: наявність навчальних посібників, виданих різними мовами, національних іграшок, серії дидактичних картин, які б знайомили дітей з культурою народів інших національностей, що проживають у даному полікультурному просторі, застосування інноваційних технологій навчання мов і т. ін.

Сукупність стимульованих чинників розвитку мовлення і навчання мов, постійне перебування мовця від дошкілля до випускного класу школи в активно-стимульованому полікультурному мовленнєвому середовищі $€$ запорукою формування як кінцевого результату навчально-мовленнєвої діяльності багатомовної особистості громадянина нашої країни.

Зауважу, що шляхи формування мовної особистості педагога вже сьогодні закладено в низку концепцій розбудови мовної освіти в Україні такими вченими, як Н.В. Бондаренко, І.К. Гудзик, Л.І. Мацько, С.Я. Єрмоленко та ін.

Насамперед слід усім нам добре усвідомити, що виховання мовної особистості в нашій країні передусім багато в чому залежить від стану вивчення української мови в усіх навчальних закладах національних спільнот від дошкілля до вищої школи.

Потрібна наскрізна перспективна програма її вивчення, що буде орієнтувати як педагогів, так і студентів, і учнів на засвоєння живої української літературної мови, на вільне володіння нею, на «розширення і збагачення словника до такої міри, щоб кожна людина вільно спілкувалась українською мовою в усіх мовленнєвих ситуаціях, сприймала мову, як явище національної культури і мистецтва і діставала від цього естетичне задоволення» [13:69].

Бездоганне знання учнями рідної і державної мов виступить позитивним підгрунтям для подальшого опанування ними у процесі шкільного і вишівського навчання іноземних мов. Саме такий підхід до мовної освіти забезпечить мовну стабільність у багатонаціональній державі, що є найважливішим фактором формування багатомовної особистості.

1. Агадуллін Р.Р. Полікультурна освіта: методолого-теоретичний аспект.- Зб.: «Педагогіка і психологія». - Вип. 3 (44). - К.: «Педагогічна преса», 2004.

2. Бахтин М.М. Искусство слова и смеховая культура // Контекст. - 1972. - М.: Наука, 1973.

3. Бацевич Ф.С. Основи комунікативної лінгвістики. - К.: «Академія», 2004.

4. Богин Г.И. Модель языковой личности в её отношении к разновидностям текстов. - Л., 1984.

5. Бондаренко Н.В. Концепція шкільної мовної освіти національних спільнот України. - Зб.: «Педагогіка і психологія» - Вип. 3 (8).- K., 1995.

6. Гачев Г. Национальные образы мира.- М.: Сов. Писатель, 1988.

7. Гукаленко О.В. Поликультурное образование: методологические и технологические контексты // Славянская педагогическая культура. - 2003.- №2.

8. Гумбольт Вильгельм фон. Избранные труды по музыкознанию.- М.: Прогресс, 1984.

9. Єрмоленко С.Я., Мацько Л.І. Навчально-виховна концепція вивчення української мови.// Початкова школа. - $1995 .-$ №1.

10. Каракулов Ю.Н. Русский язык и языковая личность.- М., 1987.

11. Леонтьев А.А. Основы психолингвистики.- М.: Смысл, 1997.

12. Маслова В.А. Лингвокультурология. - М.: «Академия», 2001.

13. Мацько Л.І. Українська мова: формування національної свідомості // Педагогіка і психологія. - 1996.- №1.

14. Миропольська Н.Є. Мистецтво слова у структурі художньої культури учня. - К.: Парламентське видавництво, 2002.

15. Соссюр Фердинанд де. Труды по языкознанию.- М.: Просвещение, 1977.

16. Сухомлинський В.О. Вибрані твори в 5 т. - т. 3. - К.: «Рад. шк.», 1977.

\section{Reference}

1. Agadullin R.R. Polikul'turna osvita: metodologo-teoretychnyj aspekt.- Zb.: «Pedagogika i psykhologiya». - Vyp. 3 (44). - K.: «Pedagogichna presa», 2004.

2. Bakhtyn M.M. Iskusstvo slova i smekhovaya kul'tura // Kontekst. - 1972. - M.: Nauka, 1973.

3. Bacevych F.S. Osnovy komunikatyvnoyi lingvistyky. - K.: «Akademiya», 2004.

4. Bogyn G.Y. Model` yazykovoj lichnosti v yeye otnoshenii k raznovidnostiam tekstov. - Lviv, 1984.

5. Bondarenko N.V. Koncepciya shkil'noyi movnoyi osvity nacional’nykh spil’not Ukrayiny. - Zb.: «Pedagogika i psykhologiya» - Vyp. 3 (8). - K., 1995.

6. Gachev G. Nacional'nye obrazy mira. - M.: Sov. Pisatel', 1988.

7. Gukalenko O.V. Polikul'turnoe obrazovaniye: metodologicheskiye i tekhnologicheskie konteksti // Slavyanskaya pedagogicheskaya kul'tura. - 2003. - №2.

8. Gumbol’t Vylgel’m fon. Izbrannyie trudy po muzikoznaniyu. - M.: Progress, 1984.

9. Yermolenko S.Ya., Macz`ko L.I. Navchal'no-vykhovna koncepciya vyvchennya ukrayins`koyi movy.// Pochatkova shkola. - 1995. - №1.

10. Karakulov Yu.N. Russkij yazyk i yazikovaya lichnost'. - M., 1987.

11. Leont'ev A.A. Osnovy psikholingvistiki. - M.: Smisl, 1997.

12. Maslova V.A. Lingvokul'turologiya. - M.: «Akademiya», 2001.

13. Macz`ko L.I. Ukrayins`ka mova: formuvannya nacional’noyi svidomosti // Pedagogika i psykhologiya. - 1996. - №1.

14. Myropol's`ka N.Ye. Mystecztvo slova u strukturi khudozhn`oyi kul'tury uchnya. - K.: Parlaments`ke vydavnycztvo, 2002.

15. Sossyur Ferdinand de. Trudy po yazykoznaniyu. - M.: Prosveshheniye, 1977.

16. Sukhomlyns kyj V.O. Vybrani tvory v 5 t. - t. 3. - K.: «Rad. shk.», 1977. 